\title{
PEMBUATAN BIOBRIKET DARI LIMBAH DEDAUNAN
}

\author{
Farham HM.Saleh ${ }^{1}$, Riffi Restu Hadi ${ }^{2}$, Adiliawan Imam As Shidiq ${ }^{3}$, \\ Sari Ayu Nyimas Genyai ${ }^{4}$, Gita Kencana Pertiwi ${ }^{5}$ \\ Jurusan Teknik Kimia Fakultas Teknologi Indutri Universitas Islam Indonesia \\ Sleman, Yogyakarta, Indonesia \\ E-mail:farham.saleh@gmail.com
}

\begin{abstract}
There were so many leaves waste in our environment. This reseach is conduct to study the possibility of using that waste as a raw material of Bio-briquettes. The leaves that useare mangoes, jackfruits, rambutans, and teak wood powder as comparison. Bio-briquettes were make with and without pyrolysis, for 2 and 5 gram starch. The characteristics test, flame test and water boiling test are conducted with Anglo and Biomassa Stove. The results of the test shows that only moisture content that meet SNI, but the good information that the calories of three type of leaves are more than 4,600 calories/gram, especially the rambutan leaves is 4960 calories/gram. The SNI standar for wood is 5,000 caloris/gram. The flame test results shows that at Biomassa Stove better than at Anglo, and 2 gram starch better than 5 gram. For water boiling test at Angglo is better than at Biomassa Stove, and 2 gram starch better than 5 gram.
\end{abstract}

Keywords : Bio-Briquett, Leaves Waste, Anglo, Biomassa Stove.

\section{PENDAHULUAN}

Bahan Bakar Minyak (BBM) merupakan sumber energi yang paling banyak digunakan, baik oleh perkantoran, transportasi, umum, industri skala besar sampai usaha mikro (UM) seperti pedagang keliling dan pedagang Angkringan. Kebutuhan akan BBM selalu meningkat setiap tahunnya sehingga diperkirakan pada 25 tahun yang akan datang, ketersediaan cadangan BBM di Indonesia akan habis. BBM merupakan energi fosil yang tidak dapat diperbaharui sehingga membutuhkan alternatif guna mengganti sumber energi tersebut dengan sumber energi yang terbaharukan. UM umumnya menggunakan BBM jenis gas yaitu gas melon sebagai bahan bakarnya dan sebagian menggunakan "briket" arang kayu. Saat sekarang harga gas melon Rp 26.000/tabung (Kedaulatan Rakyat, 2016). Arang kayu juga persediaannya semakin terbatas dan harganya relative mahal. Oleh karena itu perlu dicari energi alternatif sebagai pengganti BBM dan arang kayu bagi UM. Salah satu alternatif yang dapat dipertimbangkan adalah limbah dedaunan (biomassa)karena sifatnya yang dapat diperbaharui, relatif tidak mengandung unsur sulfur sehingga tidak menyebabkan polusi udara dan persediaannya tidak terbatas.

Penelitian ini mencoba membuat biobriket dari dedaunan di antaranya daun mangga, daun rambutan, daun nangka dan serutan kayu jati sebagai pembanding. Biobriket yang dihasilkan akan diuji coba pada Anglo dan Kompor Biomassa. Pada uji coba ini akan diukur berapa lama waktu biobriket dapat dimanfaatkan hingga semuanya menjadi abudan berapa lama waktu yang dibutuhkan untuk mendidihkan $1 / 2$ liter air. Selain itu akan diukur nilai kalornya dan akan dibandingkan dengan nilai kalor briket kayu menurut standar SNI.

Beberapa penelitian tentang pembuatan briket bioarang dari limbah pertanian telah dilakukan di antaranya oleh Santoso, dkk Tampubolon dan Wilasita dan Ragil Beberapa penelitian tersebut lebih focus pada parameter nilai kalor yang diperbandingkan dengan nilai kalor kayu 
standar SNI, belum diteliti faktor tentang penggunaan briket tersebut.

Penelitian ini mencoba untuk membuat briket dedaunan (biobriket) dengan tujuan untuk dapat dimanfaatkan khususnya oleh pedagang keliling dan pedagang angkringan. Beberapa parameter yang diuji di antaranya nilai kalor, lama nyala api sampai menjadi abu dan lama waktu yang dibutuhkan untuk mendidihkan $1 / 2$ liter air.

\section{METODE PENELITIAN}

Bahan - bahan yang digunakan dalam penelitian ini adalah limbah daun mangga, daun nangka, daun rambutan dan serutan kayu, perekat (kanji), minyak jelantah dan air. Adapun alat - alat yang digunakan dalam penelitian diantaranya Timbangan digital, Hydraulic press, Reaktor pirolisis, Ayakan, Media cetak briket, Anglo dan Kompor biomassa. Dalam penelitian ini yang akan diukur adalah karakteristk biobriket sesuai SNI, lama nyala api dan lama waktu untuk pendidihan air.

Limbah daun mangga, daun nangka, daun rambutan dan serutan kayu, dijemur panas sinar matahari selama 3 hari. Daun mangga, daun nangka dan daun rambutan selanjutnya diporong kecil - kecil kemudian diblender, sedangkan serutan kayu dipotong kecil - kecil, ditumbuk halus kemudian dimasukkan crusher. Selanjutnya semua bahan yang telah halus tersebut diayak. Ketiga macam daun masing - masing dibagi dua, sebagian untuk diproses pirolisis sedangkan sebagian lainnya langsung dibuat biobriket dengan dicampur dengan kanji dan minyak jelantah.
Proses yang sama juga dilakukan pada bahan baku serutan kayu. Komposisi bahan yang tidak melalui pirolisis ada 2 (dua) macam yaitu 15 gram bahan +5 gram kanji $+30 \mathrm{ml}$ air $+10 \mathrm{ml}$ minyak jelantah dan 15 gram bahan +2 gram kanji $+10 \mathrm{ml}$ air +10 $\mathrm{ml}$ minyak jelantah. Sebagian lain dari daun mangga, daun nangka dan daun rambutan langsung dipirolisis. Bahan hasil pirolisis dicampur dengan kanji dengan dua komposisi seperti sebelumnya tanpa minyak jelantah. Selanjutnya masing - masing campuran tersebut dibuat menjadi biobriket dengan cara dikempa atau dipress, sehingga dihasilkan biobriket. Sebagian biobriket dedaunan baik yang tanpa melalui proses pirolisis maupun yang melalui proses pirolisis diuji karakteristiknya di Laboratorium Pusat Studi Pangan dan Gizi PAU UGM, sedangkan sebagian lainnya bersama biobriket serutan kayu dilakukan uji lama nyala api dan uji pendidihan air pada sarana Anglo dan Kompor Biomassa.

\subsection{Hasil Penelitian dan Pembahasan}

Hasil pengujian terhadap biobriket dedaunan dan serutan kayu sebagai pembanding yang dihasilkan ditunjukkan beberapa tabel di bawah ini.

\subsubsection{Karakteristik Biobriket}

Hasil pengujian karakteristik biobriket yang dilakukan di Laboratorium Pusat Studi Pangan dan Gizi PAU Universitas Gajah Mada (UGM) meliputi beberapa parameter sesuai standar SNI yaitu kadar air, kadar volatil, kadar abu, kadar karbon terikat dan nilai kalor biobriket yang ditunjukkan pada tabel 1. 
Tabel 1. Karakteristik Biobriket Hasil Penelitian

\begin{tabular}{|c|c|c|c|c|c|c|}
\hline No & Bahan & $\begin{array}{c}\text { Kadar } \\
\text { Air }(\%)\end{array}$ & $\begin{array}{c}\text { Kadar } \\
\text { volatil }(\%)\end{array}$ & $\begin{array}{c}\text { Kadar } \\
\text { Abu (\%) }\end{array}$ & $\begin{array}{c}\text { Kadar } \\
\text { Karbon } \\
\text { Terikat }(\%)\end{array}$ & $\begin{array}{c}\text { Nilai } \\
\text { Kalori } \\
\text { (Kalori/gr } \\
\text { am) }\end{array}$ \\
\hline \multirow{4}{*}{1.} & & 4,41 & 56,19 & 20,41 & 18,98 & 3589,59 \\
\hline & Biobriket Daun & 4,35 & 56,31 & 20,54 & 18,81 & 3680,31 \\
\hline & Mangga (DM) & 4,59 & 56,15 & 20,33 & 18,93 & 3635,20 \\
\hline & Rata-rata: & 4,45 & 56,22 & 20,42 & 18,91 & 3635,03 \\
\hline \multirow{4}{*}{2.} & & 4,62 & 51,36 & 27,72 & 16,29 & 3529,43 \\
\hline & Biobriket Daun & 4,71 & 51,45 & 27,55 & 16,28 & 3499,47 \\
\hline & Nangka (DN) & 4,76 & 51,32 & 27,62 & 16,29 & 3447,95 \\
\hline & Rata-rata: & 4,69 & 51,38 & 27,63 & 16,29 & 3492,28 \\
\hline \multirow{4}{*}{3.} & Biobriket Daun & 4,93 & 58,40 & 13,27 & 23,39 & 3742,32 \\
\hline & Rambutan & 5,05 & 58,36 & 13,18 & 23,41 & 3808,49 \\
\hline & (DR) & 4,86 & 58,56 & 13,41 & 23,16 & 3723,47 \\
\hline & Rata-rata: & 4,95 & 58,44 & 13,29 & 23,32 & 3758,09 \\
\hline \multirow{4}{*}{4.} & Biobriket DM & 5,11 & 20,86 & 35,07 & 38,95 & 4689,49 \\
\hline & (dengan & 5,17 & 20,60 & 35,17 & 38,05 & 4780,95 \\
\hline & pirolisis) & 5,25 & 20,76 & 35,03 & 38,95 & 4724,68 \\
\hline & Rata-rata: & 5,18 & 20,74 & 35,09 & 38,98 & 4734,71 \\
\hline \multirow{4}{*}{5.} & Briket & 5,31 & 18,55 & 38,91 & 37,22 & 4657,58 \\
\hline & Bioarang DN & 5,49 & 18,43 & 38,71 & 37,36 & 4575,18 \\
\hline & (dgn pirolisis) & 5,46 & 18,36 & 38,82 & 37,35 & 4627,95 \\
\hline & Rata-rata: & 5,4207 & 18,45 & 38,82 & 37,31 & 4620,24 \\
\hline \multirow{4}{*}{6.} & Briket & 5,54 & 23,15 & 24,53 & 46,78 & 4931,18 \\
\hline & Bioarang DR & 5,58 & 23,30 & 24,60 & 46,51 & 4999,47 \\
\hline & (dg pirolisis) & 5,63 & 23,39 & 24,56 & 46,42 & 4950,35 \\
\hline & Rata-rata: & 5,58 & 23,28 & 24,56 & 46,57 & 4960,33 \\
\hline \multicolumn{2}{|r|}{ Standar SNI } & $\leq 5 \%$ & $\leq 15 \%$ & USA $60 \%$ & $\leq 5 \%$ & 5000 \\
\hline
\end{tabular}

Tabel 3.1 menunjukkan bahwa hanya parameter kadar air yang memenuhi standar SNI yaitu $<8 \%$, sedangkan parameter lainnya belum memenuhi. Namun demikian dari sisi nilai kalor, biobriket daun rambutan hasil proses pirolisis mempunyai nilai kalori rata - rata sebesar 4960,3355 kalori/gram sedangkan standar SNI untuk briket kayu sebesar 5000 kalori/gram. Selain itu biobriket lain hasil proses pirolisis nilai kalorinya $>4600$ kalori/gram sedangkan yang tanpa pirolisis $<3400$ kalori per gram. Dari data hasil penelitian tersebut dapat disimpulkan bahwa biobriket dedaunan dengan proses pirolisis cukup baik digunakan pada usaha mikro karena nilai kalorinya $>4600$ kalori/gram mendekati standar SNI: 5000 kalori/gram.

\subsubsection{Uji Nyala Api dan Pendidihan Air}

Uji nyala api dan uji pendidihan air dilakukan untuk memberikan gambaran implementatif pemanfaatan biobriket yang dihasilkan. Gambaran implementatif dimaksudkan pada pemanfaatan langsung biobriket untuk pedagang keliling. Dalam uji nyala api dan uji pendidihan air, digunakan 2 (dua) biobriket dengan nilai kalori yang relative tinggi yaitu daun rambutan dan daun mangga tanpa proses pirolisis, yang akan diperbandingkan dengan briket serutan kayu 
Tabel 2 Hasil Uji Nyala Api Biobriket pada Kompor Biomassa

\begin{tabular}{c|c|c|c|c}
\hline \multirow{2}{*}{ Bahan baku } & \multicolumn{3}{|c|}{ Pengukuran ke- , menit } & \multirow{2}{*}{$\begin{array}{c}\text { Rata-rata, } \\
\text { menit }\end{array}$} \\
\cline { 2 - 4 } & $\mathbf{1}$ & $\mathbf{2}$ & $\mathbf{3}$ & 13,67 \\
Serutan Kayu Jati & 14,45 & 13,12 & 13,04 & 15,40 \\
Daun Rambutan & 16,04 & 15,45 & 14,23 & 15,16 \\
Daun manga & 15,45 & 14,44 & 15,01 & \\
\hline
\end{tabular}

Tabel 3 Hasil Uji Nyala Api Biobriket pada Anglo

\begin{tabular}{c|c|c|c|c}
\hline \multirow{2}{*}{ Bahan baku } & \multicolumn{3}{|c|}{ Pengukuran ke- , menit } & Rata-rata, \\
\cline { 2 - 4 } & $\mathbf{1}$ & $\mathbf{2}$ & $\mathbf{3}$ & menit \\
\hline Serutan Kayu Jati & 16,36 & 11,38 & 14,59 & 14,41 \\
Daun Rambutan & 16,30 & 15,09 & 16,34 & 16,07 \\
Daun manga & 15,23 & 15,55 & 15,04 & 15,46 \\
\hline
\end{tabular}

Tabel 4. Hasil Uji Nyala Api pada Anglo

\begin{tabular}{c|c|c|c|c}
\hline \multirow{2}{*}{ Bahan baku } & \multicolumn{3}{|c|}{ Pengukuran ke- , menit } & Rata-rata, \\
\cline { 2 - 4 } & $\mathbf{1}$ & $\mathbf{2}$ & $\mathbf{3}$ & 12,88 \\
\hline Serutan Kayu Jati & 12,21 & 13,04 & 13,13 & 13,38 \\
Daun Rambutan & 13,09 & 14,00 & 13,01 & 13,12 \\
Daun manga & 11,17 & 13,37 & 13,57 & \\
\hline
\end{tabular}

jati, juga tanpa proses pirolisis. Komposisi bahan uji ada 2 (dua) yaitu pertama dengan penambahan 5 gram kanji dengan komposisi: 15 gram bahan +5 gram kanji $+30 \mathrm{ml}$ air + $10 \mathrm{ml}$ minyak jelantah. Kedua dengan komposisi: 15 gram bahan +2 gram kanji + $10 \mathrm{ml}$ air $+10 \mathrm{ml}$ minyak jelantah. Penambahan minyak jelantah dengan pertimbangan bahwa minyak jelantah merupakan limbah dan memperbaiki kualitas nyala api. Untuk bahan briket dengan jumlah campuran 15 gram bahan +2 gram kanji + $10 \mathrm{ml}$ air $+10 \mathrm{ml}$ minyak jelantah, dilakukan uji nyala api dan pendidihan air dengan sarana Anglo, yang lebih aplikatif pada pedagang keliling.

Dalam melakukan kedua uji di atas, maka sarana uji yang digunakan adalah Anglo dan Kompor Biomassa dengan spesifikasi yang menyesuaikan dengan kompor biomassa dengan paten No.: P00201100604. Hasil pengujian ditunjukkan beberapa tabel pada sub bab 3.2.1 dan sub bab 3.2.2. Dalam melakukan uji pendidihan air, maka jarak antara biobriket dengan panci berisi air dikondisikan sama.

\subsubsection{Uji Lama Nyala Api}

Tabel 4.2 dan Tabel 4.3 merupakan hasil uji nyapa api untuk komposisi biobriket 15 gram bahan +5 gram kanji $+30 \mathrm{ml}$ air +10 ml minyak jelantah pada Anglo dan Kompor Biomassa, sedangkan Tabel 4.4 merupakan hasil uji biobriket dengan komposisi 15 gram bahan +2 gram kanji $+10 \mathrm{ml}$ air $+10 \mathrm{ml}$ minyak jelantah.

Tabel 2 dan tabel 3 menunjukkan bahwa rata - rata lama waktu nyala api untuk ketiga macam biobriket pada sarana Anglo lebih lama dibandingkan dengan pada sarana Kompor Biomassa. Berdasarkan pengamatan yang dilakukan hal ini disebabkan oleh pembakaran yang merata pada seluruh sisi biobriket pada sarana Kompor Biomassa, sehingga bisa habis terbakar lebih cepat dibandingkan dengan biobriket pada sarana Anglo, yang nyala apinya tidak merata pada semua sisi. Keadaan ini menunjukkan tingkat efisiensi pembakaran yang lebih baik pada kompor biomassa. Dari tabel 2 dan tabel 3 disimpulkan bahwa penggunaan sarana Anglo pada usaha mikro lebih baik dibandingkan dengan Kompor Biomassa karena rata - rata lama waktu nyala api lebih lama. 
Tabel 5 Hasil Uji Pendidihan Air Biobriket pada Kompor Biomassa

\begin{tabular}{c|c|c|c|c}
\hline \multirow{2}{*}{ Bahan baku } & \multicolumn{3}{|c|}{ Pengukuran ke- , menit } & \multirow{2}{*}{$\begin{array}{c}\text { Rata-rata, } \\
\text { menit }\end{array}$} \\
\cline { 2 - 4 } & $\mathbf{1}$ & $\mathbf{2}$ & $\mathbf{3}$ & 8,79 \\
Serutan Kayu Jati & 9,23 & 8,11 & 8,49 & 10,53 \\
Daun Rambutan & 8,45 & 11,43 & 11,08 & 10,76 \\
Daun manga & 9,13 & 11,00 & 12,04 & \\
\hline
\end{tabular}

Tabel 6 Hasil Uji Pendidihan Air pada Sarana Anglo

\begin{tabular}{c|c|c|c|c}
\hline \multirow{2}{*}{ Bahan baku } & \multicolumn{3}{|c|}{ Pengukuran ke- , menit } & Rata-rata, \\
\cline { 2 - 4 } & $\mathbf{1}$ & $\mathbf{2}$ & $\mathbf{3}$ & 10,56 \\
Serutan Kayu Jati & 10,17 & 10,28 & 10,55 & 12,57 \\
Daun Rambutan & 12,41 & 13,01 & 12,02 & 11,01 \\
Daun mangga & 10,16 & 11,50 & 10,56 & \\
\hline
\end{tabular}

Tabel 7 Hasil Uji Pendidihan Air pada Sarana Anglo

\begin{tabular}{c|c|c|c|c}
\hline \multirow{2}{*}{ Bahan baku } & \multicolumn{3}{|c|}{ Pengukuran ke- , menit } & \multirow{2}{*}{$\begin{array}{c}\text { Rata-rata, } \\
\text { menit }\end{array}$} \\
\cline { 2 - 3 } & $\mathbf{1}$ & $\mathbf{2}$ & $\mathbf{3}$ & 8,03 \\
Serutan Kayu Jati & 8,06 & 8,01 & 7,59 & 9,12 \\
\cline { 1 - 1 } Daun Rambutan & 9,15 & 8,47 & 9,20 & 10,12 \\
\hline Daun mangga & 8,40 & 10,57 & 10,45 & \\
\hline
\end{tabular}

Selanjutnya tabel 3 dan tabel 4 menunjukkan perbandingan lama nyala api antara campuran biobriket 5 gram kanji dengan 2 gram kanji. Kedua tabel menunjukkan bahwa untuk jumlah kanji yang lebih banyak maka rata - rata lama nyala api untuk ketiga macam biobriket lebih lama nyala api. Hal ini menunjukkan bahwa jumlah kanji yang dicampurkan dengan bahan lain untuk membuat biobriket berpengaruh terhadap lama nyala api. Sampai pada batas tertentu, lebih besar jumlah campuran kanji dalam biobriket maka nyala api lebih lama. Hal lain yang juga perlu dikemukakan bahwa lama nyala api untuk biobriket serutan kayu lebih singkat dibandingkan dengan dua biobriket dedaunan lain. Hal ini mungkin disebabkan porositas biobriket kayu lebih tinggi sehingga relatif lebih mudah untuk terbakar semuanya. Kesimpulannya bahwa semakin besar jumlah kanji pada biobriket, maka lama waktu nyala api lebih lama.

\subsubsection{Uji Pendidihan Air}

Tabel 5 dan tabel 6 merupakan hasil uji pendidihan air untuk komposisi biobriket 15 gram bahan +5 gram kanji $+30 \mathrm{ml}$ air +10 ml minyak jelantah pada Anglo dan Kompor Biomassa, sedangkan Tabel 4.7 merupakan hasil uji biobriket dengan komposisi 15 gram bahan +2 gram kanji $+10 \mathrm{ml}$ air $+10 \mathrm{ml}$ minyak jelantah.

Tabel 5 dan Tabel 6 menunjukkan bahwa rata-rata lama waktu pendidihan $1 / 2$ liter air untuk ketiga macam biobriket pada sarana Anglo lebih lama dibandingkan dengan pada sarana Kompor Biomassa. Hal ini mungkin disebabkan kalori yang terbawa oleh api pembakaran biobriket pada Anglo kurang terarah atau kurang fokus karena sifatnya yang lebih terbuka. Keadaan ini menunjukkan tingkat efisiensi pembakaran yang lebih baik pada kompor biomassa. Dapat disimpulkan bahwa perlu desain Anglo yang lebih efisien pemanfaatan panasnya.

Selanjutnya tabel 6 dan tabel 7 menunjukkan perbandingan lama waktu pendidihan $1 / 2$ liter air campuran biobriket 5 gram kanji dengan 2 gram kanji. Kedua tabel menunjukkan bahwa untuk jumlah kanji yang lebih banyak maka justru rata-rata lama waktu pendidihan untuk ketiga macam biobriket lebih singkat. Hal ini mungkin disebabkan nilai bakar kanji lebih kecil 
sehingga dengan jumlah kanji yang lebih banyak nyala api lebih lama tetapi jumlah kalori yang tersalurkan relatif lebih sedikit. Dapat disimpulkan bahwa jumlah kanji yang lebih banyak dalam biobriket maka lama waktu pendidihan air lebih singkat.

\section{KESIMPULAN}

Dedaunan baik melalui proses pirolisis maupun tanpa melalui proses pirolisis dapat dibuat menjadi biobriket, namun dengan proses pirolisis dapat menghasilkan nilai kalor yang mendekati standar SNI untuk kayu. Nilai kalor biobriket daun rambutan sebesar 4960,33 kalori/gram sementara standar SNI $5000 \mathrm{kalori} / \mathrm{gram}$, sehingga layak untuk dijadikan biobriket utamanya untuk UM pedagang keliling.

1. Rata - rata lama nyala api biobriket yang digunakan pada Anglo lebih lama dibandingkan dengan yang digunakan pada Kompor Biomassa.

2. Rata - rata lama nyala api biobriket dengan jumlah campuran kanji 5 gram, lebih lama dibandingkan dengan jumlah campuran kanji 2 gram.

3. Rata - rata lama waktu pendidihan $1 / 2$ liter air pada kompor biomassa lebih cepat dibandingkan dengan pada Anglo

4. Rata - rata lama waktu pendidihan $1 / 2$ liter air pada biobriket dengan campuran 2 gram kanji lebih cepat dibandingkan dengan campuran 5 gram.

\section{DAFTAR PUSTAKA}

Harian Kedaulatan Rakyat, 2016. 9 September.

Santosa, Mislaini, dan Swara. 2010. Studi Variasi Komposisi Bahan Penyusun Briket Dari Kotoran Sapi Dan Limbah Pertanian. Skripsi Jurusan Teknik Pertanian. Fakultas Teknologi ertanian. Universitas Andalas. Padang.

Tampubolon., 2001. Pembuatan Briket Arang Kotoran Sapi Perah dengan Penambahan Tempurung Kelapa. Skripsi Jurusan Ilmu Produksi Ternak. Fakultas Peternakan. Institut Pertanian Bogor.

Wilasita dan Ragil, 2011. Pemanfaatan Limbah Tongkol Jagung dan Tempurung Kelapa Menjadi Briket Sebagai Sumber Energi Alternatif dengan Proses Karbonisasi dan Non Karbonisasi. Skripsi Jurusan Teknik Kimia. Fakultas Teknologi Industri Institute Teknologi Sepuluh November (ITS). Surabaya, 